IWONA ARABAS

Instytut Historii Nauki

im. L. i A. Birkenmajerów

Polskiej Akademii Nauk

ODRCID: 0000-0002-1194-984X

\title{
Innowacje w rolnictwie - tradycje i współczesność. Pamięci księżnej Anny z Sapiehów Jabłonowskiej
}

W 2020 r. przypadała 220. rocznica śmierci księżnej Anny z Sapiehów Jabłonowskiej i z tej okazji odbyła się międzynarodowa konferencja pod tytułem „Innowacje w rolnictwie - tradycje i współczesność. Pamięci księżnej Anny z Sapiehów Jabłonowskiej”. Organizatorami tego wydarzenia, przy wsparciu finansowym Ministerstwa Nauki i Szkolnictwa Wyższego z Programu „Doskonała nauka”, były: Instytut Historii Nauki im. Ludwika i Aleksandra Birkenmajerów PAN, Societas Scientiarum Klukoviana et Jablonovianae oraz Muzeum Rolnictwa im. ks. Krzysztofa Kluka w Ciechanowcu. Data została ustalona początkowo na maj, ale ze względu na pandemię COVID-19 konferencja odbyła się online w dniach 18-19 września $2020 \mathrm{r}$.

Duże zainteresowanie wielokierunkową działalnością księżnej Anny Jabłonowskiej, szczególnie wśród historyków regionów Podlasia i Lubelszczyzny, oraz tradycje zielarskie na tych terenach zainspirowały organizatorów do rozszerzenia tematyki wykraczającej poza historię nauki.

Celem konferencji było przedstawienie, ciągle jeszcze niedocenianej, postaci księżnej Anny Jabłonowskiej jako wzoru kobiety obywatela, innowatorki w dziedzinie rolnictwa i zarządzania gospodarką rolną oraz pionierki badań przyrodniczych. Jej nowatorska na naszych ziemiach działalność $\mathrm{w}$ zakresie aklimatyzacji roślin może być inspirująca także współcześnie, szczególnie ze względu na ciągłość tradycji uprawy ziół na Podlasiu i Lubelszczyźnie. 
Referaty wygłoszone na Konferencji przez historyków i historyków nauki zostały skonfrontowane z wypowiedziami specjalistów z zakresu rolnictwa, farmacji i botaniki zajmujących się współcześnie podobną problematyką, jaką zajmowała się księżna. Taki dwugłos pozwolił na podkreślenie znaczenia innowacji dla uprawy, hodowli i aklimatyzacji roślin użytkowych, które wprowadzała księżna Anna Jabłonowska.

Na stronie Konferencji zarejestrowało się blisko 100 osób, a uczestniczyło w niej ponad 75 osób (m.in. z wyższych uczelni, instytucji muzealnych, międzynarodowych towarzystw naukowych oraz instytucji kultury i samorządów lokalnych z Polski, Francji, Wielkiej Brytanii, Niemiec, Rosji, Ukrainy i Włoch). Konferencja została zarejestrowana i jest dostępna na stronie: https://jablonowska-konferencja. pl/informacje oraz podlinkowana do stron: Instytutu Historii Nauki PAN, Polskiego Towarzystwa Farmaceutycznego oraz Warszawskiej Okręgowej Izby Aptekarskiej. W jej trakcie wygłoszono 21 referatów w czterech sesjach. Ich autorami byli uczestnicy z Polski, Rosji i Ukrainy. Wystąpienia wywołały bardzo twórczą i ciekawą dyskusję prowadzoną po zakończeniu każdej sesji.

Obrady otworzył dr hab. Jacek Soszyński, prof. PAN, dyrektor Instytutu Historii Nauki PAN, oraz Dorota Łapiak, dyrektorka Muzeum Rolnictwa w Ciechanowcu, a pierwszą sesję poprowadziła prof. dr hab. Joanna Partyka. Tło historyczne dla głównego tematu, jakim było ukazanie wszechstronnej działalności Jabłonowskiej, przedstawili w referatach dr Jarosław Kurkowski - „Państwa w państwie?”. Uwagi o roli magnaterii u schytku istnienia I Rzeczypospolitej oraz prof. dr hab. Zofia Zielińska - Klimat wychowawczy środowiska Anny z Sapiehów Jabłonowskiej w świetle pamiętników jej stryja - biskupa Józefa Juliana Sapiehy. Omówiono w nich wybrane aspekty politycznej, społecznej i kulturalnej roli magnaterii u schyłku istnienia I Rzeczypospolitej oraz klimat wychowawczy środowiska Anny z Sapiehów Jabłonowskiej w świetle pamiętników jej stryja - bp. Józefa Juliana Sapiehy.

Kolejne referaty dotyczyły powiązań Anny Jabłonowskiej ze środowiskiem przyrodników, czerpania inspiracji w kręgu rodziny oraz sytuacji ekonomicznej jej sąsiadów na Podlasiu. W tej części sesji referaty wygłosili: prof. Zbigniew J. Wójcik - Józef Rostafiński (1850-1928) o księżnej Annie Jabłonowskiej i księdzu Krzysztofie Kluku; prof. dr hab. Wiktor Zygmunt Łyjak - Co mogło łaczyć Annę z Sapiehów Jabłonowska z księdzem Krzysztofem Klukiem; prof. dr hab. Bożena Popiołek - Gospodarskie problemy Jadwigi z Jabłonowskich Woroniczowej, 
kasztelanowej kijowskiej oraz Eryk Kotkowicz - Ziemianin podlaski wobec kryzysu lat dziewięćdziesiatych XVIII wieku na podstawie pamiętnika Michała Starzeńskiego.

Drugą sesję poprowadziła dr hab. Joanna Schiller-Walicka, prof. PAN, a tematem wiodącym były zagadnienia związane z wiedzą przyrodniczą w XVIII w. Referaty wygłosili: prof. dr hab. Joanna Partyka - Wskazówki agronomiczne w siedemnastowiecznych podręcznikach ziemiańskich J.K. Haura. Odwołanie do tradycji jako podstawa gospodarowania; Maria Śledzianowska - Zainteresowania ideami fizjokratyzmu francuskiego w Polsce w czasach działalności księżnej Anny $z$ Sapiehów Jabłonowskiej; dr Katarzyna Pękacka-Falkowska - Nie tylko Kluk i Jabłonowska... Flora rodzima w badaniach Jacoba Breyne'a; dr Lidia Maria Czyż i Sylwia Tulik - Egzotyczne rośliny $w$ dendrariach $i$ oranżeriach dworskich Podkarpacia (Medyka, Dubiecko) oraz prof. dr hab. Ludwik Frey - Podróże Aleksandra Antoniego Sapiehy - polski przyczynek do poznania przyrody batkańskiej.

W dniu 19 września III sesję poprowadziła dr hab. Iwona Arabas, prof. PAN, a wystąpienia w tej części dotyczyły tradycyjnego zastosowania roślin leczniczych i użytkowych oraz współczesnych kierunków badań, z zastosowaniem biotechnologii roślin. Referaty przedstawili: dr Wojciech J. Szypuła - Wspótczesne zastosowania widłaków wymienionych $w$ „Dykcyonarzu roślinnym” Krzysztofa Kluka; Justyna Makowska Wąs i dr hab. Irma Podolak - Leki co zastępuja inne - substytuty kiny wedtug Kluka. Substitutes of cinchona bark according to Kluk; dr Małgorzata Jeziorek, prof. dr hab. Agnieszka Pietrosiuk - Potencjat leczniczy i użytkowy barwnych pochodnych szikoniny pozyskiwanych $z$ Boraginaceae - tradycyjne zastosowania oraz wspótczesne kierunki badań z zastosowaniem biotechnologii roślin oraz Robert Księżopolski - Rośliny lecznicze i aromatyczne w Europie jako szansa rozwoju innowacyjnego rolnictwa. Raport Grupy Fokusowej EIP AGRI.

Ostatnią, IV sesję konferencji poprowadził Robert Księżopolski, a referaty odnosiły się przede wszystkim do zagadnień kolekcjonerstwa przyrodniczego i odkrywania roślin leczniczych w XVIII w. Tę tematykę podjęli: dr hab. Jacek Drobnik, prof. UMŚ - Polskie odkrycia roślin leczniczych od XVII do połowy XX w.; dr Ewa Kaczmarzyk - Dzieła ks. Krzysztofa Kluka jako przykład pierwszych rozpraw botanicznych z systemem Linneusza na ziemiach polskich; dr hab. Iwona Arabas, prof. PAN i dr hab. Larysa Bondar - Rośliny egzotyczne w dobrach Anny Jabłonowskiej: uprawa i obecność w siemiatyckim Gabinecie Historii Naturalnej; dr hab. Piotr Daszkiewicz, prof. PAN 
- Anna Jabłonowska, kolekcje gadów i płazów, a herpetologia w Rzeczypospolitej $w$ XVIII wieku oraz dr Dmytro Kepin - A history of museum work in Ukraine in the period of 15th-18th centuries.

Zaprezentowane referaty na tej interdyscyplinarnej konferencji łączą historię i historię nauki ze współczesnymi badaniami z zakresu agronomii, botaniki farmaceutycznej i farmakognozji. Prowadzone dzisiaj badania wskazują, że na decyzję o wyborze gatunków do poszukiwania w nich nowych związków leczniczych często mają wpływ prowadzone od wieków obserwacje i badania nad uprawą oraz aklimatyzacją roślin. Na ziemiach polskich $\mathrm{w}$ tej dziedzinie prym wiodła księżna Anna Jabłonowska, wprowadzając w swoich majątkach gospodarcze innowacje i sprowadzając egzotyczne rośliny, również lecznicze, z najodleglejszych zakątków świata. Jestem przekonana, że pokazanie działalności księżnej Anny Jabłonowskiej na Podlasiu i Lubelszczyźnie przyczyni się do zainicjowania w przyszłości projektów badawczych i popularyzujących naukę, łączących historię z najnowszymi badaniami. 